\title{
Skilled migrants in the Middle East: definitions, mobility and integration
}

\author{
William S. Harvey and Dimitria Groutsis
}

Forthcoming in International Journal of Business and Globalisation

\begin{abstract}
This paper focuses on skilled migrants moving to and integrating in the Middle East. We provide a series of factors to help conceptualise this heterogeneous group. The paper looks at various types of skilled migration, mobility and integration as well as the challenges that individual migrants have faced. We argue that when thinking about migration and integration, it is important to appreciate multiple scales of analysis. We also highlight that although skilled migrants have confronted a number of migration and integration barriers, many have also experienced additional challenges on the basis of their identity.
\end{abstract}

\section{Keywords}

Skilled migrants; Middle East; definitions; mobility; integration; scale

\section{Introduction}

In the last two decades there has been a steady growth of research on skilled migrants in multiple regions at different points in time (see Al Ariss and Özbilgin, 2010; Beaverstock, 2002, 2005; Groutsis, 2009; Harvey, 2011a, 2011b; Iredale, 2001; Koser and Salt, 1997; Ley, 2010; Richardson and McKenna, 2003; Saxenian, 2006; Yeoh and Willis, 2005). This research has focused on a range of topics, including but not limited to: immigration, return migration, brain drain, brain waste, brain circulation, government immigration policy, integration, finding work, expatriate and impatriate assignments, social networks and gender inequality. Relatively little research has focused on the careers of skilled migrants within the Middle-East which is surprising given the economic growth of the region as well as the large volume of international migration (World Bank, 2011).

The definition of the 'Middle East' is not clear and there is no exact list of countries that the region includes because of political, historical, economic and cultural factors. This is problematic when analysing migration to, within and from the region because numbers and trends may vary depending upon how we define the Middle East. For the purposes of clarity, we follow the United Nation's classification of the Middle East and North Africa (MENA) (see Table 1).

The Middle East is a particularly important region for focusing on migration for a number of reasons. First, it has a large population of over 330 million and a growing economy with the region's gross domestic product (GDP) growth averaging 5\% between 2005-2009 (see Table 1). In contrast, the United States has a slightly smaller population of 307 million and an average GDP growth between this period of $1.2 \%$. These figures are significant in terms of international migration because 
neoclassical economic theory of migration suggests that migrants will move to countries with better wages, which exist in countries with higher GDPs. Second, it has a large stock of immigration with the average country having $24.4 \%$ of its total population born abroad. It should be highlighted that there is a large degree of variation across the Middle East (standard deviation of 26.6), from Qatar, which has a foreign-born population of $86.5 \%$, to Morocco, which has a foreign-born population of $0.2 \%$. Third, the Middle East as a whole as well as countries within the region have experienced a large stock of emigration, including an exodus of people with tertiary education, which is contributing to a brain drain. Fourth, a number of countries such as Lebanon and Jordan receive significant remittances as a percentage of their GDP and therefore it is important to appreciate the role of the Middle Eastern diaspora in driving economic growth in the region (see Table 2). 
Table 1: Population Data on the Middle East

\begin{tabular}{|c|c|c|c|c|c|c|}
\hline $\begin{array}{l}\text { Middle Eastern } \\
\text { Country }\end{array}$ & $\begin{array}{l}\text { Population } \\
\text { in } 2009 \\
\text { (millions) }\end{array}$ & $\begin{array}{l}\text { Average } \\
\text { annual GDP } \\
\text { Growth } \\
\text { from 2005- } \\
2009(\%) \\
\end{array}$ & $\begin{array}{l}\text { Stock of } \\
\text { Emigrants } \\
\text { in } 2010 \text { (\% } \\
\text { of total } \\
\text { population) }\end{array}$ & $\begin{array}{l}\text { Emigration } \\
\text { of tertiary- } \\
\text { educated } \\
\text { population } \\
\text { (\%) }\end{array}$ & $\begin{array}{l}\text { Stock of } \\
\text { Immigrants } \\
\text { in } 2010 \text { (\% } \\
\text { of total } \\
\text { population) }\end{array}$ & $\begin{array}{l}\text { Inward } \\
\text { Remittance } \\
\text { Flows in } \\
2009 \\
\text { (millions) }\end{array}$ \\
\hline Algeria & 34.9 & 3.7 & 3.4 & 9.4 & 0.7 & $2,059.0$ \\
\hline Bahrain & 0.8 & 7.3 & 3.7 & 4.9 & 39.1 & $\mathrm{n} / \mathrm{a}$ \\
\hline Djibouti & 0.9 & 4.8 & 11.0 & 11.0 & 13.0 & 28.0 \\
\hline Egypt & 83.0 & 6.0 & 4.4 & 4.6 & 0.3 & $7,150.0$ \\
\hline Iran & 72.9 & 4.5 & 1.7 & 14.5 & 2.8 & $1,045.0$ \\
\hline Iraq & 31.5 & 4.1 & 4.9 & 11.1 & 0.3 & $\mathrm{n} / \mathrm{a}$ \\
\hline Israel & 7.4 & 4.1 & 14.0 & 7.9 & 40.4 & $1,267.0$ \\
\hline Jordan & 6.0 & 7.2 & 11.3 & 7.2 & 45.9 & $3,597.0$ \\
\hline Kuwait & 2.8 & $n / a$ & 8.5 & 7.1 & 68.8 & $\mathrm{n} / \mathrm{a}$ \\
\hline Lebanon & 4.2 & 5.3 & 15.6 & 38.6 & 17.8 & $7,558.0$ \\
\hline Libya & 6.4 & 5.5 & 1.7 & 2.4 & 10.4 & 14.0 \\
\hline Malta & 0.4 & $n / a$ & 26.2 & 57.6 & 3.8 & 45.0 \\
\hline Morocco & 32.0 & 4.8 & 9.3 & 17.0 & 0.2 & $6,271.0$ \\
\hline Oman & 2.8 & $n / a$ & 0.5 & 0.6 & 28.4 & 38.0 \\
\hline Qatar & 1.4 & $n / a$ & 0.7 & 2.5 & 86.5 & $\mathrm{n} / \mathrm{a}$ \\
\hline Saudi Arabia & 25.4 & $n / a$ & 0.7 & 0.9 & 27.8 & 217.0 \\
\hline Syria & 21.1 & 4.6 & 4.2 & 6.1 & 9.8 & $1,332.0$ \\
\hline Tunisia & 10.4 & 4.7 & 6.3 & 12.5 & 0.3 & $1,966.0$ \\
\hline United Arab Emirates & 4.6 & $n / a$ & 1.2 & 1.0 & 70.0 & $\mathrm{n} / \mathrm{a}$ \\
\hline West Bank and Gaza & 4.0 & $n / a$ & 68.3 & 7.2 & 43.6 & $1,261.0$ \\
\hline Yemen & 23.6 & 3.9 & 4.7 & 6.0 & 2.1 & $1,378.0$ \\
\hline Mean & 17.9 & 5.0 & 9.6 & 11.0 & 24.4 & $2,201.6$ \\
\hline Median & 6.4 & 4.8 & 4.7 & 7.2 & 13.0 & $1,299.5$ \\
\hline Standard deviation & 23.1 & 1.1 & 14.8 & 13.5 & 26.6 & $2,570.0$ \\
\hline \multicolumn{7}{|l|}{$\begin{array}{l}\text { Selected country } \\
\text { outside of the Middle } \\
\text { East }\end{array}$} \\
\hline USA & 307.0 & 1.2 & 0.8 & 0.5 & 13.5 & $2,947.0$ \\
\hline UK & 61.8 & 0.6 & 7.5 & 16.7 & 11.2 & $6,847.0$ \\
\hline China & $1,331.5$ & 11.4 & 0.6 & 3.8 & 0.1 & $48,729.0$ \\
\hline India & $1,155.3$ & 8.2 & 0.9 & 4.3 & 0.4 & $49,256.0$ \\
\hline Australia & 21.9 & 2.9 & 2.1 & 2.7 & 25.7 & $4,089.0$ \\
\hline
\end{tabular}

Source: World Bank (2011)

We agree with the editors that exploring the careers of skilled immigrants in the Middle East is of critical importance, not least because there are multiple forms of migration associated with the region. Although a lot of international migration derives from within the Middle East, there are a significant number of skilled migrants who are moving to the Middle East from outside of the region. The average Middle Eastern country, for example, is losing $11 \%$ of its tertiary educated population abroad, with countries such as Lebanon and Morocco losing as much as $38.6 \%$ and $17 \%$, respectively. A disaggregation of this data would provide a more nuanced illustration of the professional and occupational groups emigrating from the region. Unfortunately, it is not clear how 
these figures compare to the average intake of tertiary-educated migrants and further research is needed to establish whether there is a net loss of tertiary-educated migrants.

When analysing the data on top destination and source countries in the Middle East, we found a startling asymmetry in the types of countries people were moving to and from. Developed countries such as the United States, Canada and the United Kingdom were the most popular countries of destination, whereas developing countries such as Egypt, Pakistan and the Philippines were the most popular source countries (see Table 2). We know that 12 million immigrants are entering the Middle East and North Africa compared to 18.1 million emigrants leaving the region (World Bank, 2011). This illustrates a net loss of migrants, but as we discussed above what we do not know is the relative skillsets of immigrants and emigrants. However, we know that $63.4 \%$ of emigrants are moving to high income OECD and non-OECD countries, whereas $65.3 \%$ of immigrants are refugees (World Bank, 2011). This suggests that most Middle Eastern emigrants are moving to developed countries, whereas the majority of immigrants moving to the Middle East are from developing countries. This raises concern as it suggests a major imbalance in both the number and skillset of immigrants and emigrants. Therefore, an analysis of skilled migrants in the Middle East is important within the academic and policy realm.

This paper provides an overview of the literature on skilled migrants moving to and integrating in the Middle East. This is significant because although we have some broad structural understanding of the flows, social characteristics and barriers for migrants into and out of the Middle East, we know less about their individual experiences of moving and finding work. We justify why this is a significant area of inquiry by providing an overview of the literature on skilled migrants, focusing on three important aspects. First, the definitions of skilled migrants where we attempt to clarify our understanding of this diverse group. Second, their mobility which includes a brief overview of what drives them to migrate. Third, their experiences of integration, including challenges of language, accreditation, finding work and the cultural environment. The above issues are significant in the context of the Middle East where relatively little research has been conducted on skilled migrants compared to other regions despite the economic significance of the region as well as the large flow of migrants of all skillsets. 
Table 2: Top Destination and Top Source Countries

\begin{tabular}{|c|c|c|c|c|c|}
\hline Rank & $\begin{array}{l}\text { Top Destination } \\
\text { Countries (number } \\
\text { of times cited as a } \\
\text { top ten destination } \\
\text { for each MENA } \\
\text { country) }\end{array}$ & $\begin{array}{l}\text { Top Source } \\
\text { Countries } \\
\text { (number of times } \\
\text { cited as a top ten } \\
\text { source for each } \\
\text { MENA country) }\end{array}$ & $\begin{array}{l}\text { Top emigration } \\
\text { countries within } \\
\text { MENA }\end{array}$ & $\begin{array}{l}\text { Top immigration } \\
\text { countries within } \\
\text { MENA }\end{array}$ & $\begin{array}{l}\text { Remittances } \\
\text { (\% of GDP) }\end{array}$ \\
\hline 1 & $\begin{array}{l}\text { The United States } \\
\text { (20) }\end{array}$ & Egypt (10) & Egypt & Jordan & $\begin{array}{l}\text { Lebanon } \\
\text { (22.4) }\end{array}$ \\
\hline 2 & Canada (19) & Pakistan (7) & Morocco & Syria & $\begin{array}{l}\text { Jordan } \\
(15.6)\end{array}$ \\
\hline 3 & $\begin{array}{l}\text { The United Kingdom } \\
\text { (17) }\end{array}$ & Philippines (7) & $\begin{array}{l}\text { West Bank and } \\
\text { Gaza }\end{array}$ & Iran & $\begin{array}{l}\text { Morocco } \\
(6.6)\end{array}$ \\
\hline 4 & Germany (16) & Sudan (7) & Iraq & $\begin{array}{l}\text { West Bank and } \\
\text { Gaza }\end{array}$ & Tunisia (5.3) \\
\hline 5 & Australia (13) & $\begin{array}{l}\text { India (6), Iraq (6), } \\
\text { Sri Lanka (6), Syria } \\
\text { (6), West Bank } \\
\text { and Gaza (6) }\end{array}$ & Iran & Lebanon & Yemen (5.2) \\
\hline
\end{tabular}

Source: World Bank (2011)

\section{Defining skilled migrants}

Skilled migration remains poorly defined within the theoretical literature as well as within the political domain and as a result this cohort of migrants have remained invisible (Findlay, 1995; Counihan, 2009). A combination of factors have led to this lack of specificity, including the political nature of defining skilled migrants as well as the varying practices of collecting data on this heterogeneous group at a country and company level (Freeman, 2005; Couihan, 2009; Dumont et. al. 2010; Harvey, 2009; Groutsis and Arnold, 2010). Skilled migration comprises a broad range of professions and occupational categories (Iredale, 2000; Richardson and Lester, 2004; Green et al., 2005; Chiswick et al., 2005; Junankar and Mahuteau, 2005; Allsop et. al., 2009). In addition, skilled migrants may be transferred through inter or intra-firm arrangements (Tharenou and Harvey, 2006; Al-Rajhiet., al. 2006), as well as self-initiated movers (Al-Ariss and Ozbilgin, 2010). For those who are supported in their move by an organizational infrastructure, the transfer invariably results in entry into a position that is commensurate to their pre-migration skills and qualifications (Funakawa, 1997; Harzing, 2001). For those self-initiated migrants, the process is somewhat more complex, requiring them to navigate their way into the host country labour market and thus shoulder the financial and non-financial risks involved in the migration, settlement and integration process (AlAriss et. al., forthcoming). A further complication with defining skilled migration surrounds the identity characteristics which construct perceptions of individual ability and, as a corollary, shape the individual's adaptability in the host country labour market in a position representative of their skills and qualifications. Gender, age, ethnicity, country of training and country of vocational experience 
are merely a few of many ways in which skilled migrants are selected based upon their identity characteristics (Madhi and Barrientos, 2003:71; Triandafyllidou and Wodak, 2003).

Given the many defining characteristics that construct the profile of skilled migrants, disaggregating various features of this group can help to better explain and understand the impact of skilled migration on the home and host countries as well as on the individual migrants. In doing so we are one step closer to making this group more visible and in the process developing our approaches to data collection, collation and exchange between home and host countries.

We would suggest that the following seven factors should be considered when seeking to define skilled migrants:

(i) The nature of the migration (e.g. self-initiated, family-driven, or inter/intra-firm).

(ii) The proposed period of migration (temporary, circular or permanent). This is often dependent on the geographical proximity of the host country in relation to the home country as well as the location of family members.

(iii) The labour market, political, social and lifestyle conditions in the host country (pull factors).

(iv) The labour market, political, social and lifestyle conditions in the home country (push-factors).

(v) The migrant's skills and qualifications, including human capital resources such as tertiary education as well as achieved workplace skills.

(vi) The migrant's access to various forms of indigenous, migrant, work, recreational and family networks in the host country.

(vii) The migrant's ascribed identity characteristics such as gender, age and ethnicity.

These factors are not mutually exclusive, but rather form an interdependent sum of characteristics that together help to shape and predict migration and labour market choices and outcomes. Thus, our integrated model is an important starting point for analysing and understanding skilled migration and integration.

\section{Mobility}

Migration into the Middle East, whether via inter- or intra-company transfer or as a result of selfinitiated migration has tended to be primarily temporary or circular, rather than permanent. This organised, legal, open and flexible approach to labour mobility is said to foster migration flows into and out of countries strictly for work rather than settlement purposes (Agunias and Newland, 2007). This approach to labour mobility is considered of benefit for all parties involved and a number of assumptions are made regarding stakeholder outcomes:

(i) Home countries gain from the flow of remittances in the short- to medium-term and from the retention of skilled and externally trained labour in the medium- to long-term. 
(ii) Host countries gain from an immediate response to labour needs, without the cost- and time-investment in training. Furthermore, they are absolved of the financial investment in the requisite settlement infrastructure, which is bound to permanent migration.

(iii) Employers in the host country benefit from access to a pool of skilled labour when required.

(iv) Migrants benefit from overseas experience which may foster their career development over the long-term. They are considered integral in facilitating economic development in their home countries through remittances. Also, through retaining their pre-existing skills and through acquiring new skills while working in the host country, they are able to integrate into the home country labour market upon return (Bonache et. al. 2001; Hugo, 2009; Koser, 2009; OECD, 2007; Vertovec, 2007; UNFPA, 2006; IOM, 2005, 2008).

Through analysing migration at a macro scale it is possible to appreciate the significance of immigration to the Middle East. However, it is not only macro level structural factors which are important in dictating the migration of skilled workers, but also factors at a meso- and micro-level. In the context of international migration, our understanding of the macro scale includes government policies on immigration, the meso scale includes the social networks held between migrants, institutions and other actors, and the micro scale includes individual-level decisions (see Table 3). Indeed, arguably many skilled migrants, particularly the highly skilled, are in such high demand by governments and institutions that there are few disincentives at a macro level which affect their movement. Having said this, as political developments at the beginning of 2011 have demonstrated, national-level politics within the Middle East have a critical influence on individual behaviour, including on international migration trends. The Defence Ministry Director in Israel, Udi Shani, for example, said that the national power struggle in Egypt has led to a fall in international migration across the Sinai desert border to Israel because of the rise of individual interest and participation in the political transition in Egypt (Reuters, 2011).

Table 3: Macro, meso and micro scales of migration analysis

\begin{tabular}{|l|l|}
\hline $\begin{array}{l}\text { Scale of migration } \\
\text { analysis }\end{array}$ & Example of factors \\
\hline Macro & $\begin{array}{l}\text { Immigration policy at a supranational, } \\
\text { national and local level. Political dynamics, a } \\
\text { country's laws, history and cultural norms. }\end{array}$ \\
\hline Meso & $\begin{array}{l}\text { The social networks between migrants and } \\
\text { other institutions, firms and individuals } \\
\text { (migrants and non-migrants) in the host, } \\
\text { home and other countries }\end{array}$ \\
\hline Micro & $\begin{array}{l}\text { Knowledge, resources and decision-making } \\
\text { made at an individual level. }\end{array}$ \\
\hline
\end{tabular}

Much of the literature on skilled migrants has focused on the movement of professionals between global cities (Beaverstock and Smith, 1996; Findlay et al., 1996; Malecki and Ewers, 2007; Ong, 2007). This is an important area of research given the concentration of economic activity within these regional economies (Sassen, 2001). However, it is significant to consider that many skilled migrants move between non-global cities (Saxenian, 2006; Harvey, 2011a, 2011b). This is relevant because if we were to analyse the Globalisation and World Cities (GaWC) (2008) classification of World Cities, there are no cities in the Middle East that are classified in the top four categories of Alpha++, Alpha+, Alpha and Alpha-cities and only three cities (Tel Aviv, Riyadh and Cairo) in the 
Beta+ category. This shows that there are few cities in the Middle East which are well connected by global standards within the world city network. However, as we have shown earlier, immigration to the Middle East is highly significant. So, why does extensive international migration exist in a region which is relatively unconnected to the global economy? There is an interesting paradox: "In the Arab Gulf, flows of labor and their embodiment in local labor markets serve as the key process in global city formation, yet are absent from traditional indicators of world city status" (Malecki and Ewers, 2007, p. 473).

At a macro scale, countries and cities have recognised that in order to be economically competitive they need to attract and retain top talent (Ong, 2007). This demand to attract and retain talent has led to the phrase 'the war for talent' which insinuates that there are winners and losers (Chambers et al., 1998). At the micro and meso level, microeconomic theories of migration argue that individuals will move to places where they expect to maximise their return in the labour market (Sjaastad, 1962; Borjas, 1999) and the new economics of labour migration theory argues that the family and household level of analysis is an important scale of investigation because this group make strategic choices based on diversifying their resources in order to reduce their income risk (Stark, 1978; de Haas, 2010). In the last four decades, the significant economic growth within the Middle East, particularly around the oil and construction sectors, coupled with attractive immigration policies has enabled the region to attract skilled foreign talent. Iredale (2002), for example, argues that the Middle East is a significant regional case in terms of attracting skilled workers because most skilled workers around the world are moving from less developed to more developed countries.

The neo-classical economic approach to migration assumes that individuals migrate to new labour markets to achieve higher financial returns than in their home country. McGovern (2007) argues that migrants are rational and weigh-up the costs and benefits of moving to a host country versus staying in the home country. Employers are also portrayed as having a purely economic motivation in their relationship with migrant labour. For example, it is assumed that the employer draws labour on a 'needs only' basis, when prompted by labour shortages (McGovern, 2007). In the neo-classical approach it is assumed that labour is simply another factor in the production process. Having said this, a number of migration scholars have appreciated the importance of non-economic factors in influencing migration decisions. Massey and Espinosa (1997), for instance, highlight that migrants are motivated to move to new markets as a result of factors beyond work, including social and personal connections. Thus, the reason skilled migrants transfer their skills abroad is also dependent on and shaped by non-institutional and non-economic factors (Kloosterman et. al. 1998;

Kloosterman et. al. 1999). The issue of family, for instance, is of critical importance because many skilled migrants often move without their spouses or children and as a result they often wish to return to their home country. Other skilled migrants have ageing and ailing parents in their home country who they want to return to. These family ties may not only shorten how long skilled migrants remain in a host country, but also in the process hamper their ability to work in jobs that reflect their qualifications and skills because they have less time to gain workplace recognition and therefore promotion.

What is less clear is whether many skilled workers are attracted to stay in the Middle East. This raises the important question at a macro level about whether these countries want many skilled workers to stay as permanent residents, or replace them with a new group of skilled workers. Khadria (2006), for example, argues that restrictions have been imposed since the mid-1970s 
through fear of the foreign-born population rapidly growing. As a case in point, Saudi Arabia has on the one hand allowed all nationalities to apply for citizenship, but at the same time has increased the residency period for naturalisation from five to ten years (Baldwin-Edwards, 2005). This is an important area for future research because it appears that some Middle Eastern governments and institutions want to 'attract and replace' rather than 'attract and retain' talent. Having said this, at the time of writing this paper, Kuwait was considering offering foreign workers citizenship to attract more expatriates (Gulfji, 2011). In short, when considering the careers of skilled migrants in the Middle East, although their mobility is important, it is also critical to understand whether migration policies are focused on long-term or short-term migration as this has a significant impact upon the experience of integration for existing migrants, which in turn influences whether potential future migrants decide to make the economic and cultural 'investment' in moving to the Middle East.

It is important to distinguish between various types of skilled migrants in the Middle East. Many skilled migrants in the Middle East are born in countries outside of the region, while many others are born in a Middle Eastern country, but are working in another country within the region. We would argue that it is critical not to assume that these groups have the same motives for moving because the dynamics in their home country are likely to vary significantly. Equally, there may be differences within these categories. For example, skilled British migrants might have different reasons for moving to Dubai than skilled Indian migrants. Similarly, skilled migrants from Qatar might have varied reasons for moving to the United Arab Emirates than skilled migrants from Lebanon. It is beyond the scope of this paper to explore these nuances, but further empirical research is needed to understand why skilled migrants from different countries move into, within and out of the Middle East.

\section{Integration}

Our definition of integration suggests that migrants face varying challenges in the workplace, home and family life as well as more broadly in social and community life. In the workplace, they face difficulties with obtaining jobs, acquiring employment and tasks at a level equivalent to their qualification and training, as well as challenges with being accepted and respected by their employers and colleagues. In the home, they may have problems obtaining visas and residency, finding and affording housing in their neighbourhoods of choice, and feeling safe and accepted within their community. In their social lives, they face challenges with gaining access to public services, meeting new people and forming social relationships, and joining social clubs and societies. For those with families, the integration process must also be managed with their dependant's needs in mind. Family issues are also significant for skilled migrants who move independently because, as we have discussed above, they typically have family members in their home country which may hamper their ability to settle in the host country. In addition, many migrants frequently speak a different first language to the people in the host country and are therefore 'audibly different' to the host population. They are also often 'visibly different' from the host population because of identity characteristics, including physical body shape and size, skin and eye colour, or in what they wear. Historically, many of these characteristics have meant that migrants have been marginalised in the workplace, home and in their social lives, impacting on the integration process. Migrants face additional challenges because of geography and time. Experiences of integration into one country, region, city or neighbourhood, for example, will be very different from others because of varying 
macro-, meso- and micro-level factors. The timing of migration is also important because in the past migrants have received markedly different levels of welcome by governments, institutions and individuals. Typically, they have been hailed during periods of economic growth, but marginalised during periods of economic stagnation. Finally, integration is not a static process because as skilled migrants spend longer time periods in the host country they participate more in host country networks, which in most instances fosters the integration process.

It is important to distinguish between migration and integration because although they are separate phenomena, they have tended to be conflated at a policy level. Successfully immigrating to a host country or returning to a home country, for example, may be defined as moving safely and legally, whereas successfully integrating into a host country or reintegrating into a home country includes, but is not limited to: finding work at the equivalent level to one's training, understanding the language and cultural norms, securing housing and feeling part of a local community. The Middle East has been a region which has attracted large numbers of workers from multiple countries with a cross-section of skillsets. In Saudi Arabia, for example, employment trebled between 1970 and 1980 and doubled between 1980 and 1995, with most of these workers originating from abroad (Madhi and Barrientos, 2003). It is important to distinguish between immigration and integration because in the case of the Middle East although many Gulf countries, for instance, imported a large volume of skilled labour in the 1970s to meet the demands of a booming economy, their governments made it clear that: "[...] these workers would not be allowed to permanently settle or bring their families, a situation that has not changed" (Castles and Miller, 2009, p. 3). This again suggests that some Middle Eastern countries prefer an immigration system of 'attract and replace' rather than 'attract and retain'. The implication of this is that migrants are able to move to the region for temporary periods of time to fill labour shortages, but are unable to remain legally. They are also less likely to stay because of national laws about bringing their families to the Middle East during the period of their work contracts. For many migrant groups, their integration has been hampered because they do not speak the language in the host country, which excludes them from certain types of employment as well as participation in social clubs and societal activities. As Dustmann (1994) rightly argues, strong verbal and written language skills are integral for enabling migrants to gain employment and higher incomes.

Chain migration theory argues that once migrants successfully move and integrate into a new country, they will pass on positive signals to families, friends and contacts in their home country. In turn, this leads to more people from the same country of origin moving to the new country (MacDonald and MacDonald, 1964). However, the opposite argument presumably holds for people who experience difficulties with moving and integrating because they will pass on their negative experiences through their social networks. This is particularly relevant for skilled professionals who are in a stronger position to choose where in the world they live and work because their skills are in demand by countries and institutions and therefore they can afford not to move to places where they predict they will experience barriers to integration (Florida, 2005). This is likely to happen if they perceive the migration poses a risk. This is not the case with workers with fewer skills who hold less bargaining power because they have fewer if any paid alternatives and there are many other migrants who are willing to take the job if they do not. In other cases, many skilled workers are forced to leave their home country because of political, economic and social circumstances and as a result they also have few career alternatives and have to take whatever work they can find (Al Ariss, 2010; Al Ariss and Özbilgin, 2010). This can lead to 'brain waste' when migrants work in jobs which 
require lower levels of skills than they have acquired through their former university and/or job training (Mahroum, 2000). In addition, skilled migrants who have obtained their education and training in their home country as opposed to their host country often find themselves at a strategic disadvantage (Groutsis, 2006; Williams, 2007). This is particularly likely to occur when work practices and social norms are markedly different in both countries, causing migrants to participate in migrant networks rather than indigenous networks which creates an 'us' and 'them' division in work and everyday life (Groutsis, 2009; Harvey, 2008b).

Historically, the volume of immigrants in the Middle East has been dominated by men working in masculine sectors such as extractives and construction. In the last few decades there has been a rise in the migration rates of women, who currently comprise $50 \%$ of the world's immigrant population (UNFPA, 2006). They are no longer identified as partners of the principal migrant or as migrants crossing national boundaries for family reunion. Importantly, women are now migrating in their own right and are a group defined by variations in skill levels and therefore are moving for multiple reasons, deriving from various parts of the world and intending to stay for different lengths of time. Despite a more open stance towards female migrants, women, and particularly those with fewer skills, continue to be marginalised and often find themselves vulnerable: "While all workers in the Middle East have limited rights, female domestic workers are highly vulnerable to exploitation and sexual abuse, and it is difficult for the authorities of their countries of origin to provide protection" (Castles and Miller, 2009, p. 4). Walsh (2006, p. 275) describes the difficulty of one of her female respondents, Jane, feeling conspicuously foreign as she walks in the streets of Dubai dressed in Western clothing without a veil. The implication of this marginalisation is severe as it may reduce the flow of skilled labour to the region as migrants move to other global locations:

"Due to accounts of abuse regarding female migrant worker experiences (non-payment of wages, beating, long hours, sexual harassment and rape) diffusing through the South Asian countries, women are increasingly beginning to turn to more developed Asian countries as migrant destinations rather than to the Gulf States" (Malecki and Ewers, 2007, p. 476).

In summary, the labour market experience of skilled migrants cannot be understood without the given assumption that all social relationships are gendered. Historically, immigrant women in the Middle East and in many countries, for instance, have had to conform to a set of standards and expectations to which they have not contributed.

Labour market outcomes for different groups of women are also directly influenced by their ethnicity. Research combining both gender and ethnic issues has, in the main, posed problems for social scientists with many opting for an investigation of one or the other, or simply choosing to ignore both and thus compound the invisibility of skilled mobile stocks of labour (Anthias, 1992, 1993; Christou, 2006; Lutz, 2002; Richter, 2004). Malecki and Ewers (2007) argue in the context of the Gulf countries that there are multiple polarisations in the local Arab population, in the skilled western migrant population and in the low skilled, predominantly South Asian migrant population. Within the migrant population in Dubai, Walsh (2006, pp. 274-275) argues that although British expatriates are perceived as foreign by the Emirati population, they tend to hold a higher social position than the majority of the migrant population who tend to hold less skills and originate from South Asia. Castles and Miller (2009, p. 4) also hint at this migrant stratification with even those Asian migrants who occupy managerial and technical positions reporting to either a Middle Eastern 
senior manager or sometimes reporting to: "[...] senior personnel recruited from Europe or North America." Malecki and Ewers (2007, p. 478) argue that there is a distinct hierarchical social structure within the Gulf countries:

"Westerners occupy the highest social strata, as they tend to occupy the higher executive and technical positions. [...] Other Arabs from North Africa or the Levant occupy the second level of social stratum. [...] The lowest position on the social hierarchy is occupied by Asians, whether from India, Pakistan, Thailand, or the Philippines."

These arguments are highly relevant in the context of skilled migrant careers in the Middle East because it is clear that there is heterogeneity between the local and migrant populations as well as within both sets of populations.

There is likely to be strong geographical and temporal differences with the migrant experience. In addition, we know from the theoretical literature that migrant groups vary in the degree to which they use social networks for moving, integrating and finding work (Poros, 2001; Saxenian, 2006; Raghuram, 2010; Harvey, 2008a, 2011a). This is important in relation to skilled migrants integrating into the Middle East because the success individuals experience with integration may depend upon the extent to which they hold social networks with different actors and whether these networks hold particular value (social capital) that can provide them with opportunities within the workplace (Putnam, 1995; Ooka and Wellman, 2001). Bashi (2007) talks about key human connectors or 'hubs', who are similar to Gladwell's (2000) 'connectors' because they hold multiple contacts in different locations, and therefore are important in helping migrants to hear about and secure work. In Kuwait, for example, recruiters have helped over half of the migrant population from South Asia to find a job (Shah and Menon, 1999).

\section{Conclusions}

This paper has highlighted the important role of skilled migrants in the Middle East. We have shown that the region has experienced extensive economic growth alongside significant inflows and outflows of migrants. Although the term 'skilled migrant' has been poorly defined within the public and policy realm, we have indicated some ways in which this heterogeneous group may be better understood. It is tempting at a policy level to categorise skilled migrants as a homogeneous group with similar motivations and experiences, but we have argued in the context of the Middle East that they are a highly diverse population with varying backgrounds, social characteristics and cultural traits. In addition, countries within the Middle East have held different immigration and integration policies at various points in time. As a result, moving and integrating to the Middle East has been a diverse experience for the skilled migrant population.

In light of our overview of the literature and data on skilled migration definitions, mobility and integration, we would argue that there are three aspects related to the careers of skilled migrants which are worthy of further research. First, skilled migrants moving from outside to inside the Middle East. Second, skilled migrants leaving one Middle Eastern country and moving to another Middle Eastern country. Third, skilled migrants moving from a Middle Eastern to a non-Middle Eastern country. In addition to these three aspects, we would argue that it is important to focus on the macro, meso and micro-level scale because international migration and experiences of careers 
can vary in different ways and depending upon geographical, temporal, economic and social context. A company job offer (micro-level), for example, may encourage a skilled migrant to move, while extensive discussions with a migrant friend who has already moved (meso-level) may make that person indifferent about migrating, while restrictive immigration and visa policies (macro-level) may discourage that person from moving. Furthermore, the experience of migration and integration is not the same. A migrant, for example, might successfully move to the Middle East, but not successfully integrate. These considerations are important because they provide an additional layer of analysis in helping us to understand the experiences of skilled migrant careers. This paper is merely a brief start in exploring this rich but as yet relatively unmined field of inquiry.

\section{References}

Agunias Rannveig, D. and Newland, K. (2007) 'Circular Migration and Development: Trends, Policy Routes, and Ways Forward', Migration Policy Institute Policy Brief, April 2007, Washington.

Al-Ariss, A. Vassilopoulou J. Groutsis, D. Ozbilgin, M. (forthcoming) 'A Multilevel Understanding of the Careers of Minority Ethnic Elites' In: Kakabadse, A. and Kakabadse, N. (Eds) Elites: The Opaque Nature of Transnational Policy Determination, Palgrave Macmillan, London.

Al- Ariss, A. and Ozbilgin, M. (2010) 'Understanding Self- Initiated Expatriates: Career Experiences of Lebanese Self-Initiated Expatriates in France', Thunderbird International Business Review Vol. 52, No. 4 , pp. $275-285$.

Al Ariss, A. (2010). 'Modes of engagement: migration, self-initiated expatriation, and career development', Career Development International, Vol. 15, No. 4, pp. $338-358$.

Al-Rajhi, I. Altman, Y. and Metcalfe, B. (2006) 'Managing Impatriate Adjustment as a Core Human Resource Management Challenge', People and Strategy, Vol. 29, No. 4, pp. 15 - 23.

Allsop, J. Bourgeault, I. L. Evetts, J. Le Bianic, T. Jones, K. Wrede, S. (2009) 'Encountering Globalisation: Professional Groups in an International Context', Current Sociology, Vol. 57, No.4, pp. $487-510$.

Anthias, F. (1992) Ethnicity, Class, Gender and Migration, Avebury, London.

Anthias, F. (1993) 'Gendered Ethnicities in the British Labour Market', In: Rudolph, H. and Morokvasic, M (eds), Bridging States and Markets, Sigma, Berlin, pp. 163-191.

Baldwin-Edwards, M. (2005) Migration in the Middle East and Mediterranean. Mediterranean Migration Observatory, Greece.

Bashi, V. F. (2007) Survival of the knitted: immigrant social networks in a stratified world, Stanford University Press, Stanford, CA.

Beaverstock, J.V. (2002) 'Transnational elites in global cities: British expatriates in Singapore's financial district', Geoforum, Vol. 33, No. 4, pp. $525-538$.

Beaverstock, J.V. (2005) 'Transnational elites in the city: British highly-skilled inter-company transferees in New York City's financial district', Journal of Ethnic and Migration Studies, Vol. 31, No. 2, pp. $245-268$. 
Beaverstock, J.V. and Smith, J. (1996) 'Lending Jobs to Global Cities: Skilled International Labour Migration, Investment Banking and the City of London', Urban Studies, Vol. 33, No. 8, pp. 1377 1394.

Bonache, J. Brewster, C. and Suutari, V. (2001) 'Expatriation: a developing agenda', Thunderbird International Business Review, Vol. 43, No. 1, pp. 3-20.

Borjas, G. J. (1990) Friends or Strangers: The Impact of Immigrants on the U.S. Economy, Basic Books, New York.

Borjas, G. J. (1999) 'The economic analysis of immigration', Handbook of Labor Economics, 3 (Part 1), $1697-1760$.

Castles, S. and Miller, M.J. (2009) 'Migration in the Asia-Pacific Region', Migration Information Source - Migration in the Asia Pacific Region. Published in: July, 2009. Accessed on: $17^{\text {th }}$ February, 2011. Url: http://www.migrationinformation.org/Feature/display.cfm?id=733

Chambers, E. G., Foulton, M., Handfield-Jones, H., Hankin, S. M., \& Michaels, E. G., III (1998) 'The war for talent', McKinsey Quarterly, Vol. 3, pp. $44-57$.

Chiswick, B. Lee, Y. \& Miller, P. (2005) 'A longitudinal analysis of immigrant occupational mobility: a test of the immigrant assimilation hypothesis', International Migration Review, Vol. 39, No. 2, pp. $332-353$.

Couihan, C. (2009) "'Going Global": Why do Multinational Corporations Participate in Highly Skilled Migration?', Comparative Technology Transfer and Society, Vol. 7, No.1, pp. $19-42$.

Christou, A. (2006) 'Crossing boundaries - Ethnicizing employment - Gendering labor: gender, ethnicity and social capital in return migration', Social and Cultural Geography, Vol. 7, No. 1, pp. 87 102.

De Haas, H. (2010) 'Migration and Development: A Theoretical Perspective', International Migration Review, Vol. 44, No. 1, pp. $227-264$.

Dumont, J-C. Spielvogel, G. Widmaier, S. (2010) 'International Migrants in Developed, Emerging and Developing Countries: An Extended Profile', OECD Social, Employment and Migration Working Papers, No. 114.

Dustmann, C. (1994) 'Speaking fluency, writing fluency and earnings of migrants', Journal of Population Economics, Vol. 7, pp. 133-56.

Findlay, A.M., Li, F.L.N., Jowett, A.J. and Skeldon, R. (1996) 'Skilled International Migration and the Global City: A Study of Expatriates in Hong Kong', Transactions of the Institute of British Geographers Vol. 21, No. 1, pp. 49-61.

Findlay, A. M. (1995) 'Skilled transients: The invisible phenomenon?', In: Cohen, R. (ed), The Cambridge Survey of World Migration, Cambridge University Press, New York.

Florida, R. (2005) The Flight of the Creative Class. The New Global Competition for Talent, HarperCollins, New York. 
Freeman, G.P. (2005) 'Political science and comparative immigration politics', in: Bommes, M. and Morawska, E. (Eds), International Migration Research: Constructions, omissions and the promises of interdisciplinarity, Ashgate Publishing, Burlington.

Funakawa, A. (1997) Transcultural management: A new approach for global organizations, JosseyBass, San Fransisco.

GaWC (2008) 'The World According to GaWC 2008', Accessed on: $15^{\text {th }}$ February, 2011. Url: http://www.lboro.ac.uk/gawc/world2008.html

Gladwell, M. (2000). The Tipping Point. How Little Things Can Make a Big Difference. Little, Brown and Company, New York.

Groutsis, D. (2006) 'Geography and credentialism: the assessment and accreditation of overseastrained doctors', Health Sociology Review, Vol 15 No, 1, pp. $59-70$.

Groutsis, D. (2009) 'Recruiting migrant nurses to fill the gaps: the contribution of migrant women in the nursing cares sector in Greece', Journal of International Migration and Integration, Vol. 10, pp. $49-65$.

Groutsis, D and Arnold, P (2010) 'Medical Elites: Migration, Accreditation and Integration of South African Medical Professionals in Australia,' presented at Equality, Diversity and Inclusion conference, $14-16$ July, 2010, Vienna, Austria.

Gulfji (2011) 'Kuwait considering citizenship to attract more expats', Published on: $8^{\text {th }}$ February, 2011. Accessed on: $16^{\text {th }}$ February, 2011. Url: http://www.gulfji.com/NewsDetails/kuwaitconsidering-citizenship-to-attract-more-expats-2259.aspx

Harvey, W.S. (2008a) 'British and Indian expatriate scientists finding jobs in Boston', Global Networks, Vol. 8, No. 4, pp. $453-473$.

Harvey, W.S. (2008b) 'The social networks of British and Indian expatriate scientists in Boston' Geoforum, Vol. 39 No. 5, pp. $1756-1765$.

Harvey, W.S. (2009) 'British and Indian Scientists in Boston Considering Returning to their Home Countries', Population, Space and Place, Vol. 15, No. 6, pp. $493-508$.

Harvey, W.S. (2011a) 'British and Indian scientists moving to the U.S.', Work and Occupations, Vol. 38, No. 1 , pp. $68-100$.

Harvey, W.S. (2011b) 'Immigration and emigration decisions among highly skilled British expatriates in Vancouver', in Taylor et al. (Eds) Global Knowledge Workers: Diversity and Relational. Edward Elgar, Cheltenham, UK.

Harzing, A-W. (2001) 'An analysis of the functions of international transfer of managers in MNCs', Employee Relations, Vol. 23, No. 6, pp. $581-598$.

Hugo, G. (2009) 'Labour Migration for Development: Best Practices in Asia and the Pacific', ILO Asian Regional Programme on Governance of Labour Migration, Working Paper No.17, International Labour Organization, Geneva. 
International Organization for Migration (IOM). (2005) World Migration 2005: Costs and Benefits of International Migration, International Organization for Migration, Geneva.

International Organisation for Migration (IOM). (2008) Managing labour mobility in the evolving global economy', IOM World Migration Report Series, Vol. 4, International Organization for Migration, Geneva.

Iredale, R. R. (2000) 'Migration Policies for the Highly Skilled in the Asia-Pacific Region', International Migration Review, Vol. 34, No. 3, pp. $882-906$.

Iredale, R.F. (2001) 'The migration of professionals: Theories and typologies', International Migration, Vol. 39, No. 5, pp. 7-26.

Junankar, P. and Mahuteau, S. (2005) 'Do migrants get good jobs? New migrant settlement in Australia', Economic Record, Vol. 81, pp. $34-46$.

Khadria, B. (2006) 'India: Skilled Migration to Developed countries, Labor Migration to the Gulf', Migración Y Desarrollo. Accessed on: $16^{\text {th }}$ February 2011. Url:

http://www.estudiosdeldesarrollo.net/revista/rev7ing/2.pdf

Kloosterman, R. van der Leun, J. and Rath, J. (1998) 'Across the Border: Immigrants' Economic Opportunities, Social Capital and Informal Business Activities', Journal of Ethnic and Migration Studies, Vol. 24, No. 2, pp. $249-268$.

Kloosterman R. van der Leun, J. and Rath, J. (1999), 'Mixed Embeddedness: (In)formal Economic Activities and Immigrant Businesses in the Netherlands', International Journal of Urban and Regional Research, Vol. 23, No. 2, pp. $252-266$.

Koser, K. and J. Salt. (1997) 'The geography of highly skilled international migration', International Journal of Population Geography, Vol. 3, No. 4, pp. 285 - 303.

Koser, K. (2009) 'Study of Employment and Residence Permits for Migrant Workers in Major Countries of Destination', International Migration Papers No. 95, International Migration Programme, Geneva Center for Security Policy, Geneva: ILO.

Lewis, P. and Chamlee-Wright, E. (2008) 'Social embeddedness, social capital and the market process: An introduction to the special issue on Austrian economics, economic sociology and social capital', Revue of Austrian Economics, Vol. 21, pp. 107 - 118.

Ley, D., (2010) Millionaire Migrants: Trans-Pacific Life Lines, Blackwell-Wiley, Chichester, UK.

Lutz, H. (2002) 'Crossing Borders and Shifting Boundaries. Gender, Identities and Network', Opladen: Leske und Budrich, Ko-Herausgeberin.

MacDonald, J.S. and L.D. MacDonald. (1964) 'Chain Migration Ethnic Neighborhood Formation and Social Networks', The Milbank Memorial Fund Quarterly, Vol. 42, No. 1, pp. 82 - 97.

Madhi, S.T. and Barrientos, A. (2003) 'Saudisation and employment in Saudi Arabia', Career Development International, Vol. 8, No. 2, pp. $70-77$.

Mahroum, S. (2000) 'Highly skilled globetrotters: mapping the international migration of human capital', $R$ and $D$ Management, Vol. 30, No. 1, pp. $23-32$. 
Malecki, E. and Ewers, M.C. (2007) 'Labor migration to world cities: with a research agenda for the Arab Gulf', Progress in Human Geography, Vol. 31, No. 4, pp. 467 - 484.

Massey, D.S. and Espinosa, K.E. (1997) 'What's Driving Mexico-US Migration? A Theoretical, Empirical, and Policy Analysis', American Journal of Sociology, Vol. 102, No.4, pp. 939 - 999.

McGovern, P. (2007) 'Immigration, Labour Markets and Employment Relations: Problems and Prospects', British Journal of Industrial Relations, Vol. 45, No. 2, pp. $217-235$.

OECD. (2007) Policy Coherence for Development: Migration and Developing Countries, OECD, Paris.

Ooka, E. and B. Wellman. (2001) 'Does social capital pay off more within or between ethnic groups? Analyzing job searches in five Toronto ethnic groups', in E. Fong. (Ed) Inside the Mosaic, University of Toronto Press, Toronto, pp. 199-226.

Poros, M.V. (2001) 'The role of migrant networks in linking local labour markets: the case of Asian Indian migration to New York and London', Global Networks, Vol. 1, No. 3, pp. $243-60$.

Putnam, R.D. (1995) 'Bowling alone: America's declining social capital', Journal of Democracy, Vol. 6, pp. $65-78$.

Raghuram, P., Henry, L. and Bornat, J.. (2010) 'Difference and Distinction? Non-migrant and Migrant Networks', Sociology, Vol. 44, No. 4, pp. 623-641.

Reuters (2011) 'Israel says Egypt unrest stems illegal immigration'. Published on: Tuesday $8^{\text {th }}$ February, 2011. Accessed on: Tuesday $15^{\text {th }}$ February, 2011. Url:

http://af.reuters.com/article/sudanNews/idAFLDE7172EY20110208 Writing by Dan Williams; editing by Tim Pearce.

Richardson, J. and S. McKenna (2003) 'International experience and academic careers: what do academics have to say?', Personnel Review, Vol. 32, No. 6, pp. 774-795.

Richter, M. (2004) 'Contextualizing Gender and Migration: Galician Immigration to Switzerland', International Migration Review, Vol. 38, No.1, pp. $263-286$.

Sassen, S. (2001) The Global City: New York, London, Tokyo, Princeton University Press, Princeton, NJ.

Saxenian A. (2006) The New Argonauts. Regional Advantage in a Global Economy, Harvard University Press: Cambridge, MA.

Shah, N.M. and Menon, I. (1999) 'Chain migration through the social network: experience of labour migrants in Kuwait', International Migration, Vol. 37, pp. $362-381$.

Sjaastad, L. A. (1962) 'The costs and returns of human migration', Journal of Political Economy, Vol. 70, No. 5 , pp. $80-93$.

Stark, O. (1978) Economic-Demographic Interactions in Agricultural Development: The Case of Ruralto-Urban Migration. FAO, Rome.

Tharenou, P. and Harvey, M. (2006) 'Examining the overseas staffing options utilized by Australian headquartered multinational corporations', The International Journal of Human Resource Management, Vol. 17, No. 6, pp. $1095-1114$. 
Triandafyllidou, A. and Wodak, R. (2003) 'Focus: Studying Identity: Theoretical and Methodological Challenges', in Triandafyllidou, A. (Ed) Language \& Politics, Vol.2, No. 2, pp. $205-223$.

UNFPA. (2006) 'UNFPA State of World Population 2006, A passage to hope: women and international migration', Accessed on: 21 ${ }^{\text {st }}$ February, 2011, Url: http://www.unfpa.org/swp/2006.

Vertovec, S. (2007) 'Circular Migration: The Way Forward in Global Policy?', Working Papers, No. 4, International Migration Institute, James Martin $21^{\text {st }}$ Century School, University of Oxford.

Walsh, K. (2006) "Dad says I'm tied to a shooting star!' Grounding (research on) British expatriate belonging', Area, Volume 38, Issue 3, pp. 268-278.

Williams, A. M. (2007) 'International labour migration and tacit knowledge transactions: a multi-level perspective', Global Networks, Vol. 7, pp. 29-50.

World Bank (2011) 'The Migration and Remittances Factbook 2011', Compiled by Ratha, D., Mohapatra,S. and Silwal, A. Development Prospects Group, World Bank. Url:

http://econ.worldbank.org/WBSITE/EXTERNAL/EXTDEC/EXTDECPROSPECTS/0, contentMDK:213520 16 pagePK:64165401 piPK:64165026 theSitePK:476883,00.html

Yeoh, B.S.A. and Willis, K. (2005) 'Singaporeans in China: transnational women elites and the negotiation of gendered identities', Geoforum, Vol. 36, No. 2, pp. $211-22$. 